\title{
A Comparative Study on Mentor Text Modelling and Common Approaches to Teaching Writing in Iranian EFL Context
}

\author{
Farahnaz Liaghat \\ Department of English Language, Isfahan (Khorasgan) Branch, Islamic Azad \\ University, Isfahan, Iran, farahnazliaqat@gmail.com
}

\section{Reza Biria}

Corresponding author, Department of English Language, Isfahan (Khorasgan) Branch, Islamic Azad University, Isfahan, Iran, biria_reza@yahoo.com

This study aimed at exploring the impact of mentor text modelling on Iranian English as a Foreign Language (EFL) learners' accuracy and fluency in writing tasks with different cognitive complexity in comparison with two conventional approaches to teaching writing; namely, process-based and product-based approaches. To this end, 60 Iranian EFL learners in three comparison groups were taught English writing adopting one of the three approaches enumerated above. To investigate any changes in the learners' performance as a result of the study course, their fluency and accuracy in writing tasks with high, moderate, and low cognitive complexity levels were gauged before and after the training. Based on the results of covariate analysis, mentor text modelling yielded higher degree of fluency compared to a product-based approach; however, the approach was found to be inferior to a process-based approach in terms of enhancing fluency in writing. Additionally, Mentor text modelling was found to be as effective as a productbased approach, and at the same time, more effective than a process-based approach in improving accuracy, regardless of the writing tasks' cognitive complexity level. The findings may have several implications for EFL teachers and course designers interested in developing writing syllabuses.

Keywords: mentor text modelling, writing competence, accuracy, fluency, cognitive complexity

\section{INTRODUCTION}

Writing, as the chief means of expressing feelings, thoughts, desires, and plans (Akkaya \& Kirmiz, 2010), is mainly aimed at allowing people to effectively communicate in today communicative world. The prominence of writing may be better understood highlighting its significant role in assessing learners' achievement in different fields in general and in English teaching and learning in particular. On the other hand, writing is

Citation: Liaghat, F., \& Biria, R. (2018). A Comparative Study on Mentor Text Modelling and Common Approaches to Teaching Writing in Iranian EFL Context. International Journal of Instruction, 11(3), 701-720. https://doi.org/10.12973/iji.2018.11347a 
perceived by both native and non-native learners as the most challenging learning skill (Graham et al., 2005; Jahin \& Idrees, 2012). Requiring a continuous interaction between growing knowledge and production, writing requires a high level of productive language control (Luchini, 2010). Writing could become even more demanding in EFL contexts like Iran where university classes and remedial courses in English language institutes are the only opportunities students are provided with.

Given the prominent role of writing in language learning, a large number of researchers have sought to constantly improve ideas specifically related to EFL/ESL writing instruction over the past few decades. Assuming writing as a broad range of activities from the mechanical act of writing down to the highly complex act of composing (Spigelman \& Grobman, 2005), arriving at a strong consensus about the quality as well as quantity of writing instruction seems to be inconceivable, however. Among various approaches put forth for teaching writing, process and product approaches have dominated EFL/ESL writing classrooms over the last twenty years $(\mathrm{H}$. Hashemnezhad \& N. Hashemnezhad, 2012). Given the deficiency of the process and product approaches in placing simultaneous emphasis on both writing product and process, in recent years, an attempt is made to develop an alternative approach to teaching writing, namely, mentor text modeling. The approach actually relies upon the interplay between learners, mentor texts, and instructor to support English communication in EFL/ESL classrooms increasing teacher-student cooperation, teacher-student feedback, mediation, and collaboration.

This paper reports on a study into how mentor text modelling approach affect learners' accuracy and fluency in comparison with the more conventional approaches to teaching writing (i.e., process-based and product-based). Given the significant effect of writing tasks' cognitive complexity on learners' writing performance (Hamp-Lyons \& Mathias, 1994; Robinson, 2001), one pedagogical challenge would be determining whether or not the efficacy of different approaches to teaching writing could be acknowledged for writing tasks enjoying various levels of cognitive complexity. Accordingly, unlike the previous research explored the complexity of a task as a criteria to be taken into account in designing and sequencing writing courses' syllabus to facilitate maximum learning (e.g., Ellis, 2003, 2008; Nunan, 1999; Robinson, 2001, 2007), the current study aimed at determining whether manipulation of writing tasks in terms of cognitive complexity may contribute to different writing performance after being exposed to various writing instruction based on the approaches under investigation. This research paper, therefore, attempts to answer the following research questions.

1. Does mentor text modeling yield better writing performance in terms of accuracy in writing tasks with different levels of cognitive complexity in comparison with the conventional approaches to teaching writing (i.e., process-based and product-based approaches)?

2. Does mentor text modeling have any significant superiority over the conventional approaches to teaching writing in terms of fluency of tasks with different levels of cognitive complexity? 


\section{CONTEXT AND REVIEW OF THE LITERATURE}

The following sections presents a short report of the literature on the approaches under investigation in the current research study.

\section{Common Approaches to Teaching Writing in EFL Contexts}

For effective writing in EFL/ ESL classrooms, where according to Silvia (1993) organizing written materials present several difficulties for learners, research on different approaches to teaching EFL/ESL writing has grown dramatically over the last 50 years. To adopt any approach to teaching writing, as maintained by Spigelman and Grobman (2005), a variety of issues such as students' characteristics, writing assignments, and curriculum or syllabus should be taken into account. As claimed by Hasan and Akhand (2010), product approach, process approach, and genre-based approach are the major types of writing approaches in ESL/EFL contexts. Similarly, Mosayebnazhad and Assadi Aidinlou (2015) referred to product-focused, processfocused, and genre-based approaches as the most prevalent approaches to teaching writing in EFL contexts such as Iran.

\section{Product-based approach}

A product-based approach, variously known as "the controlled-to-free approach", "thetext-based approach" and "the guided composition" (Raimes, 1983; Silva, 1990), engages learners in writing employing four successive steps including presentation of writing rules, demonstration of a model text, involving learners in writing based on the model text, and correction of the learners' final product (Kroll ,1990). Relying on learners' prior knowledge of words and grammatical structures, a product-based approach mainly focuses on the ultimate written product coherence and grammatical accuracy (Nunan, 1999). Notwithstanding the efficacy of product-based approach in enhancing writing competence by raising learners' grammatical and syntactical awareness in writing (Tangpermpoon, 2008), the approach suffers from a number of disadvantages as well. Disregarding strategies, techniques, and processes which are involved in writing is assumed to be the chief drawback of the approach. (Kroll, 1990). Additionally, as asserted by Shahrokhi Mehr (2017), a product-based approach leads students to follow a number of fixed patterns, regardless of the socio-cultural factors involved in creating a written text. Moreover, although the approach is basically centered on modeling, the role of model texts in the approach is often limited to a teaching tool acting as the source of feedback to students (Saeidi \& Sahebkheir, 2011).

\section{Process-based approach}

According to Matsuda (2003), the notion of writing as process was introduced to L2 studies by Zamel (1982). Unlike the product-based approach which encourages students to write activating their syntactic, lexicon, and discourse repertoire, the process-based approach emphasizes the steps involved in drafting and redrafting a text (Nunan, 1999). The process-based approach is seen by several scholars (e.g., Sutikno, 2008; Sarhadi, 2015) to be more effective than the product based approach, inasmuch as it allows learners to explore and develop personal approach to writing. Nonetheless, the opponent of the approach often refer to the lack of a good model as its key drawback. According 
to Torghabeh et al. (2010), model can lighten the burden of devising content on learners to some degree. Moreover, as asserted by Reppen (1995), a process approach to writing is often unsuccessful in attaching appropriate importance to written form and, as a result, causes writers to craft inaccurate product in terms of the proper use of language. Additionally, a number of practitioners (e.g., Rollinson, 2005) wonder how such a timeconsuming approach demanding the employment of various pre-writing, writing, and post-writing activities can be suited to the time constraints experiencing in real setting.

\section{Mentor text modelling approach}

According to Winston (1987), mentor text modelling approach owes its origin to Christensen's (1967) study on the work of professional writers. Having tried to discover essential elements of professional writers' craft analysing different linguistic units (i.e., paragraphs, sentences, and words) in terms of style and structure, Christensen (1967) came to a conclusion that if students are exposed to professionally written texts along with the close guidance of instructors, they can craft texts which approximate to those of the professionals in terms of various features such as complexity, depth, and sophistication. This finding supported the theories underling mentor text modelling approach such as meticulous reading of mentor texts and decontextualizing such texts prior to writing. Adopting a mentor text modelling approach to teaching writing, therefore, EFL/ESL learners are instructed how to imitate mentor text for learning new ways to improve their writing competence. Mentor text modelling, as an approach which is based on socio-affective strategies in language learning and teaching realm, emphasizes interaction and cooperation between learners through pair/group work in order to reduce learners' stress, as well as learning them how to write a piece of accurate and fluent writing (Trejo, 2014).

\section{Cognitive Complexity Levels in Writing}

Task complexity, which is generally defined by Robinson (2001) as "the result of the attentional, memory, reasoning, and other information processing demands imposed by the structure of the task to the language learner" (p. 29), involves different dimensions such as code complexity, cognitive complexity, and context dependency. To provide a more specific definition, some scholars (e.g., Gilabert et al., 2009; Robinson, 2001) described task complexity as the level of variability that any particular learner experiences while performing different tasks. There are, however, other scholars (e.g., Ellis, 2003) who confined the scope of task complexity to a particular task's degree of difficulty. Cognitive complexity, which is referred to differences in intrinsic cognitive processing demands of tasks, is an index of within-learner variation in successfully completing any two tasks (Robinson, 2007).

To date, various models are proposed to categorize different levels of cognitive complexity. The most important models of task complexity are Bloom's Taxonomy (Bloom, 2001), the Depth of Knowledge (DOK) Model (Webb, 1997), and the Triadic Framework of Task Complexity (Robinson, 2005). Among the three models enumerated above, the DOK model is mainly concerned with analysing the cognitive expectation demanded by standards, curricular activities, and assessment tasks. An adapted version 
of the DOK model proposed an increasing taxonomy in terms of cognitive complexity including four levels; recall, basic application of concepts and skills, strategic thinking, and extended thinking and complex reasoning (Webb, 1997)

\section{Accuracy and Fluency in EFL Writing}

According to Skehan (1996), a common approach to determining the success of ESL/ EFL learners in writing skill would be examining accuracy and fluency of their production. Accuracy as a linguistic feature of writing performance is broadly concerned with the absence of grammatical, morphological, spelling, and punctuation errors in written texts (Polio, 2001), whereas fluency, as defined by Wolfe-Quintero et al. (1998), is "a measure of the sheer number of words or structure units a writer is able to include in his/her writing within a particular period of time" (p. 25). In simpler terms, fluency is a feature manifesting a writer's ability to generate language production, but accuracy is an indicator of a writer's ability to produce error free grammatical structures (Shahrokhi Mehr, 2017).

\section{Empirical Background}

Notwithstanding the plentitude of studies on each of the three approaches under investigation (e.g., Bayat, 2014; Balakrishnan, 2010; Jouzdani et al., 2015; Sakoda, 2008; Kane, 2012; Saeidi \& Shabkheir, 2011), no research, to the best of the researcher's knowledge, has been carried out to compare the efficacy of the three approaches in improving different linguistic components such as accuracy and fluency in writing tasks with different cognitive complexity levels. Nonetheless, as a similar attempt to recognize the most effective approach to teaching writing in an Iranian context, N. Hasheminezhad and H. Hasheminezhad (2012) performed a comparative study on product, process, and post-process approaches. The findings of their study revealed that although post-process approach did not show any significant priorities over process approach in terms of improving the learners' writing ability, both process and post-process approaches indicated significant priority over product approach. Similarly, to reach a balanced approach to be used instead of either product-based or processbased approaches, Gholami Pasand and Bazarmaj Haghi (2013) carried out a study on process-product approach and concluded that the use of an incomplete model text in such an approach to writing has a positive impact on EFL learners' accuracy in writing.

\section{METHOD}

The methodology elaborates on the research design, the participants' characteristics, the essential instruments and materials used to administer the treatment.

\section{Operational Definitions of the Study Variables}

This section reports the operational definitions of the conceptual variables.

Cognitive complexity level (CCL). To discern the alignment of the low, moderate, and high cognitive demands in writing, a modification of the Webb's (1997) DOK model was adopted. To this end, the two first levels in DOK model (i.e., 'recall' and 'basic application of skills and concepts') were considered as low CCL, whereas the other two 
levels (i.e., 'strategic thinking' and 'extended thinking and complex reasoning') were referred to as moderate and high CCL, respectively. Admitting that cognitive demands in writing increase incrementally from independent writing to integrated writing, and finally, to analytical writing, the researcher operationalized the independent, integrated, and analytical tasks as writing tasks with low, moderate, and high CCL, respectively.

Mentor texts. Being inspired by the working definition of mentor texts, the sample essays written by the most qualified test takers (rated by ETS using a score of 6 out of 6 for GRE tasks and a score of 5 out of 5 with regard to TOEFL tasks) were used as the mentor texts.

Accuracy. In agreement with what has been operationalized in a vast body of task-based research on different writing qualities (e.g., Ahmadian \& Tavakoli, 2011; Yuan \& Ellis, 2003), the present study used the ratio of error-free T-units to total T-units (EFT/T) to judge the learners writing in terms of accuracy. Following the view expressed by Ellis and Yuan (2003), the term "error" was operationalized as any deviation in syntax, morphology, and lexical choice.

Fluency. Admitting to Wolf-Quintero et al. (1998) that 'text length' is more valid than the other fluency measures such as total number of T-units or clauses, the total number of words used in each essay was considered as the working definition in measuring fluency.

\section{Participants}

The participant sample of the study was comprised of 30 male and 30 female EFL learners from Jahad Daneshgahy Institute, Tehran university branch. Employing convenience sampling method, the participants were selected from among Iranian candidates of IELTS, TOEFL, and GRE tests. The participants' English proficiency was estimated to be at upper intermediate to advanced level based on the results of a placement test administered by the institute prior to the study course. Nevertheless, a quick version of the Oxford Placement Test (QPT) was administered to all the participants and the results were used in forming three homogeneous groups, each containing $20 \mathrm{EFL}$ learners. The groups were then randomly assigned to three comparison groups called mentor-based, product-based, and process-based group.

\section{Instruments}

\section{Quick placement test ( $Q P T)$}

The QPT (second version), a quick version of the Oxford Placement Test (OPT), including 60 multiple-choice questions was used in the current study to judge learners' English proficiency. The reliability index of the test evaluated using K-R21 formula was found to be acceptable (.79).

TOFEL iBT practice tests of written English

Two different TOEFL iBT practice tests of written English, extracted from the actual TOEFL corpus, served as the pre-test and post-test in the current study. Every TOEFL iBT practice test contained two different writing tasks, namely, independent task and integrated task. The independent writing task required the participants to write an essay 
on a specific topic in 30 minutes. In the integrated task, however, the participants had 3 minutes to read a passage on an academic topic. Being allowed to take notes, the participants, then, listened to a lecture excerpt. They, finally, were to write in response to what they had read and heard in 20 minutes. Given the vast body of research carried out to investigate the reliability and comparability of TOEFL iBT Scores (see TOEFL $i B T$ Research Insight, published by ETS) the validity and reliability of the tests are selfevident

\section{GRE analytical writing practice tests}

In addition to the TOEFL independent and integrated writing tasks, two analytical writing practice tasks, selected from the GRE test corpus, examined the participants' analytical writing and critical thinking skills before and after the study course. The analytical writing measure included two separately timed (30 minutes for each task) analytical writing tasks, namely, analyse an Issue and Analyse an Argument. The Analyse an Issue task assessed the participants' critical thinking ability, as well as examining the way they express their thoughts about a topic of general interest in writing. The Analyse an Argument task, on the other hand, assessed the participants' ability to understand, analyse, and evaluate arguments according to specific instruction.

\section{Materials}

The core instructional materials of the study were comprised of six writing tasks including two independent and two integrated TOEFL iBT writing practice tasks as well as two GRE analytical writing (both argument and issue) practice tasks. To maximize the input authenticity, all writing tasks were chosen from the two latest corpus of TOEFL and GRE real tests, namely Official TOEFL iBT Tests (Volume 1, Second Edition) and The Official Guide to the GRE revised General Test.

\section{Procedure}

To guarantee the homogeneity of the study groups in terms of English proficiency, the QPT was administered to the participants and the results were utilized to form three comparison groups, each containing 10 male and 10 female learners. As the initial step toward administering the study treatment, all the participants were pretested on both the TOEFL writing practice tasks (independent and integrated) as well as the GRE analytical writing tasks (issue and argument). Subsequently, two raters (the researcher and a specialist in linguistics) analysed the participants' writings evaluating the fluency and accuracy measures. The strong correlation between scores evaluated by the two raters (fluency: $r=.732, p<.01$; accuracy: $r=.776, p<.01$ ) indicated an acceptable degree of inter-rater agreement. Having been pretested in writing proficiency, the participants of the three groups received over 26 hours of instruction during an 11-week course on advanced writing. Being exposed to the same authentic language input (a total of six writing tasks with different levels of cognitive complexity), each of the three groups received writing instruction based on one of the three approaches under investigation as the following.

Product-based writing instruction

As the first stage of the instruction, a model text representing a sample of the target writing task was read to the class. Having highlighted the important features, the 
instructor embarked to teach the language structure, lexicon, and general strategies required to accomplish the task. After devoting a couple of sessions to teaching grammar, vocabulary items, and conventions required to do the writing task, the learners commenced writing their essays exploiting what they have learned. Having analysed the learners' ultimate productions, the instructor rated the writings assigning a letter grade to each one, as well as making a brief comment about the required revisions.

\section{Process-based writing instruction}

The learners of the process-based group were initially divided into five small groups, each containing four learners. The instructor began every session brainstorming the learners' ideas about the overall purpose and structure of the target writing task. Subsequently, the learners were required to write the first draft of the task in groups. After completion of the initial drafts, the learners in each group were asked to exchange their texts with their partners, so that every learner in the group was reader of one of her/his team-mate's work. Finally, the drafts were returned and modifications were made based upon peer feedback and the final draft was written by every learner in groups. The final copies were then exchanged within the groups for proofreading and making the final comments on the essays' edition.

\section{Writing instruction based on mentor text modelling}

The learners of the mentor-based group were provided with a mentor text at the commencement of training. Subsequently, they were asked to meticulously read the text both individually and in collaborative groups. The instructor then read the text aloud and periodically stopped and highlighted specific elements such as transitional phrases, important vocabulary words, and statistics that reinforced the author's argument (if any). During the instruction, the instructor highlighted how the author used a variety of writing features including punctuation for emphasis (i.e., bullet points), word choice (i.e., idioms, jargons, and expressions), and transitional words (first, second, finally) to support his/her claims. Having fully analyzed the mentor text, the instructor tried to lay the foundations for learners' active engagement asking specific questions such as "What does this sentence do?" and "How did the writer shift the text's rhetoric?". The instructor then invited the learners to discuss their thoughts and ideas about the mentor text. Afterwards, the learners were required to do the writing task by themselves. Having accomplished the writing task, the learners spent a short period of time sharing their writing with the class. Finally, the instructor sought to elicit the learners' opinion on how successful were the essay in emulating the quality of the mentor text through learner-instructor conferences.

After completing the study treatment, the post-tests assessed any changes in the learners' writing proficiency as the results of the study course.

\section{FINDINGS}

This part sought to compare three approaches to teaching writing. 


\section{Results Related to the First Research Question}

To explore whether there is any significant difference between the three study groups in terms of accuracy in writing tasks with different CCL, the learners' accuracy scores were initially estimated calculating the ratio of error free $\mathrm{T}$-units to the total number of $\mathrm{T}$ units per text. Table 1 displays the descriptive statistics of the learners' pre-test and post-test accuracy scores, with a potential range of 0 to 1 , in the three study groups.

Table 1

Descriptive Statistics of the Pre-test and Post-test Accuracy Scores in the Three Study Groups

\begin{tabular}{|c|c|c|c|c|c|c|c|c|c|}
\hline $\mathrm{CCL}$ & Group & Variable & $N$ & Min & Max & Mean & $S D$ & Skewness & Kurtosis \\
\hline \multirow{6}{*}{ 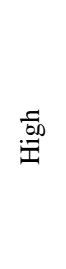 } & \multirow{2}{*}{ Mentor-based } & Pretest Scores & 20 & .493 & .661 & .588 & .044 & -.404 & -.226 \\
\hline & & Posttest Scores & 20 & .543 & .705 & .621 & .047 & -.035 & -1.007 \\
\hline & \multirow{2}{*}{ Product-based } & Pretest Scores & 20 & .454 & .694 & .603 & .059 & -.868 & .569 \\
\hline & & Posttest Scores & 20 & .532 & .749 & .641 & .057 & -.124 & -.612 \\
\hline & \multirow{2}{*}{ Process-based } & Pretest Scores & 20 & .421 & .691 & .596 & .066 & -.870 & 1.043 \\
\hline & & Posttest Scores & 20 & .454 & .694 & .600 & .061 & -.418 & .322 \\
\hline \multirow{6}{*}{ 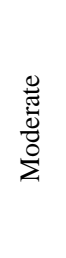 } & \multirow{2}{*}{ Mentor-based } & Pretest Scores & 20 & .533 & .783 & .655 & .076 & .115 & -1.083 \\
\hline & & Posttest Scores & 20 & .543 & .800 & .674 & .077 & .000 & -1.044 \\
\hline & \multirow{2}{*}{ Product-based } & Pretest Scores & 20 & .560 & .800 & .688 & .063 & -.300 & .140 \\
\hline & & Posttest Scores & 20 & .596 & .821 & .705 & .058 & -.152 & .071 \\
\hline & \multirow{2}{*}{ Process-based } & Pretest Scores & 20 & .533 & .800 & .669 & .064 & -.056 & .005 \\
\hline & & Posttest Scores & 20 & .560 & .800 & .672 & .062 & .368 & .273 \\
\hline \multirow{6}{*}{ 芳 } & \multirow{2}{*}{ Mentor-based } & Pretest Scores & 20 & .500 & .800 & .658 & .073 & -.313 & -.146 \\
\hline & & Posttest Scores & 20 & .571 & .800 & .689 & .066 & -.062 & -.926 \\
\hline & \multirow{2}{*}{ Product-based } & Pretest Scores & 20 & .571 & .846 & .696 & .063 & .040 & 1.068 \\
\hline & & Posttest Scores & 20 & .603 & .857 & .725 & .065 & .103 & -.048 \\
\hline & \multirow{2}{*}{ Process-based } & Pretest Scores & 20 & .543 & .818 & .688 & .063 & -.161 & .647 \\
\hline & & Posttest Scores & 20 & .562 & .821 & .697 & .061 & -.382 & .076 \\
\hline
\end{tabular}

As displayed in Table 1, the skewness and kurtosis values for all the pre-test and posttest scores were fairly small and fell within the range of $+/-2$, implying the normality of the data sets' distribution on a descriptive level (Tabachnick \& Fidell, 2007). Considering all three levels of cognitive complexity, the detailed comparison of the learners' performance on the pre and post-test measures showed a substantial increase from the pre-test to the post-test in both the mentor-based and product-based groups; however, the amount of improvement in the process-based group was quiet infinitesimal. The results also testified to a conspicuous difference between the learners' degree of accuracy in writing tasks with different CCL, suggesting that the learners' accuracy in writing correlated negatively with tasks' CCL.

A two-way analysis of covariance (ANCOVA) examined whether there was a significant main effect for the different approaches to teaching writing as well as investigating the 
significance of the interaction effect between the approaches and the tasks' CCL. Before performing the main analysis, however, all the fundamental assumptions underlying a two-way ANCOVA including normality, homogeneity of variances, and homogeneity of regression slopes were checked and no violation was witnessed.

Table 2 displays the results of the two-way ANCOVA performed on the accuracy scores in the three study groups. According to the results in Table 2, the group's effect on the posttest accuracy scores was statistically significant, $F(2,170)=13.688, p<.001$. In other words, the difference between the three groups in terms of the posttest accuracy scores was found to be statistically significant after controlling for the potential differences between them at the outset of the course (the pretest scores). Moreover, the effect size value $\left(\eta^{2}=.139\right)$ indicated that approximately $14 \%$ of the variance in the learners' final performance could be explained by the approach adopted to teaching writing. In addition, the interaction between the treatment and CCL was not statistically significant, $F(4,170)=.875, p=.480$. That is, the treatments' effect was not dependent on the writing tasks' CCL.

Table 2

Results of ANCOVA on the Accuracy Scores in the Three Study Groups

\begin{tabular}{lllllll}
\hline Source & $\begin{array}{l}\text { Type III Sum of } \\
\text { Squares }\end{array}$ & $d f$ & Mean Square & $F$ & Sig. & $\begin{array}{l}\text { Partial Eta } \\
\text { Squared }\end{array}$ \\
\hline Corrected Model & .813 & 9 & .090 & 133.419 & .000 & .876 \\
Intercept & .016 & 1 & .016 & 23.124 & .000 & .120 \\
Pretest Scores & .542 & 1 & .542 & 800.539 & .000 & .825 \\
CCL & .003 & 2 & .002 & 2.502 & .085 & .029 \\
Groups & .019 & 2 & .009 & 13.688 & .000 & .139 \\
CCL ${ }^{*}$ Groups & .002 & 4 & .001 & .875 & .480 & .020 \\
Error & .115 & 170 & .001 & & & \\
Total & 81.649 & 180 & & & & \\
Corrected Total & .929 & 179 & & & & \\
\hline
\end{tabular}

Given the significance difference between the three study groups in terms of accuracy, Table 3 shows the results of Bonferroni corrected post-hoc comparisons to determine the location of the difference based on the estimated marginal means. 
Table 3

Pairwise Comparison between the Three Groups based on the Accuracy Marginal Means

\begin{tabular}{lcccccc}
\hline \multirow{2}{*}{ (I) groups } & (J) groups & $\begin{array}{c}\text { Mean } \\
\text { Difference } \\
\text { (I-J) }\end{array}$ & $\begin{array}{c}\text { Std. } \\
\text { Error }\end{array}$ & Sig. & \multicolumn{2}{c}{$\begin{array}{c}\text { Confidence Interval for } \\
\text { Difference }\end{array}$} \\
Lower Bound & Upper Bound \\
\hline \multirow{2}{*}{ Mentor-based } & Product-based & -.004 & .005 & 1.000 & -.015 & .008 \\
& Process-based & .019 & .005 & .000 & .008 & .031 \\
\hline \multirow{2}{*}{ Process-based } & Mentor-based & .004 & .005 & 1.000 & -.008 & .015 \\
& Process-based & .023 & .005 & .000 & .012 & .035 \\
& Mentor-based & -.019 & .005 & .000 & -.031 & -.008 \\
& Product-based & -.023 & .005 & .000 & -.035 & -.012 \\
\hline
\end{tabular}

As Table 3 displays, there was a significant difference between the mentor-based and process-based groups $(p<.001)$. The difference between the process-based and productbased groups was found to be significant as well $(p<.001)$. The only non-significant difference was found between the mentor-based and product-based groups $(p=1.000)$.

\section{Results Related to the Second Research Question}

Table 4 displays the descriptive statistics of the learners' fluency scores (i.e., the average number of words written in the given time span) for writing tasks with different CCL.

Table 4

Descriptive Statistics of the Pre- and Post-test Fluency Scores in the Three Study Groups

\begin{tabular}{|c|c|c|c|c|c|c|c|c|c|}
\hline CCL & Group & Variable & $N$ & Min & Max & Mean & $S D$ & Skewness & Kurtosis \\
\hline \multirow{6}{*}{$\frac{\sqrt{00}}{10}$} & \multirow{2}{*}{$\begin{array}{l}\text { Mentor- } \\
\text { based }\end{array}$} & Pretest Scores & 20 & 521 & 705 & 626.85 & 60.73 & -.302 & -1.184 \\
\hline & & Posttest Scores & 20 & 540 & 731 & 637.05 & 58.33 & -.258 & -.953 \\
\hline & \multirow{2}{*}{$\begin{array}{l}\text { Product- } \\
\text { based }\end{array}$} & Pretest Scores & 20 & 510 & 702 & 602.95 & 71.29 & .017 & -1.644 \\
\hline & & Posttest Scores & 20 & 502 & 701 & 603.65 & 67.08 & .059 & -1.425 \\
\hline & \multirow{2}{*}{$\begin{array}{l}\text { Process- } \\
\text { based }\end{array}$} & Pretest Scores & 20 & 519 & 717 & 638.15 & 72.12 & -.597 & -1.404 \\
\hline & & Posttest Scores & 20 & 532 & 768 & 657.50 & 74.14 & -.544 & -1.219 \\
\hline \multirow{6}{*}{ 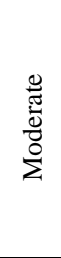 } & \multirow{2}{*}{$\begin{array}{l}\text { Mentor- } \\
\text { based }\end{array}$} & Pretest Scores & 20 & 143 & 232 & 184.80 & 27.29 & -.111 & -1.219 \\
\hline & & Posttest Scores & 20 & 139 & 239 & 190.25 & 29.03 & -.179 & -1.251 \\
\hline & \multirow{2}{*}{$\begin{array}{l}\text { Product - } \\
\text { based }\end{array}$} & Pretest Scores & 20 & 133 & 233 & 183.35 & 29.66 & -.009 & -.834 \\
\hline & & Posttest Scores & 20 & 145 & 232 & 184.55 & 26.87 & .169 & -.955 \\
\hline & \multirow{2}{*}{$\begin{array}{l}\text { Process- } \\
\text { based }\end{array}$} & Pretest Scores & 20 & 132 & 241 & 185.60 & 31.71 & .116 & -.728 \\
\hline & & Posttest Scores & 20 & 143 & 244 & 195.35 & 29.27 & -.033 & -.566 \\
\hline \multirow{6}{*}{ 3. } & \multirow{2}{*}{$\begin{array}{l}\text { Mentor- } \\
\text { based }\end{array}$} & Pretest Scores & 20 & 284 & 378 & 321.80 & 24.42 & .911 & .226 \\
\hline & & Posttest Scores & 20 & 299 & 389 & 328.80 & 21.49 & 1.335 & 1.869 \\
\hline & \multirow{2}{*}{$\begin{array}{l}\text { Product - } \\
\text { based }\end{array}$} & Pretest Scores & 20 & 288 & 361 & 320.70 & 23.05 & .528 & -.772 \\
\hline & & Posttest Scores & 20 & 265 & 369 & 319.30 & 25.96 & .074 & .060 \\
\hline & \multirow{2}{*}{$\begin{array}{l}\text { Process- } \\
\text { based }\end{array}$} & Pretest Scores & 20 & 273 & 385 & 335.50 & 32.03 & -.130 & -.997 \\
\hline & & Posttest Scores & 20 & 292 & 389 & 348.85 & 28.43 & -.409 & -.718 \\
\hline
\end{tabular}


As displayed in Table 4, in all three levels of cognitive complexity, the fluency scores improved from the pre-test to the post-test measure in the process-based and mentorbased groups; however, the difference between the pre-test and the post-test mean scores seemed to be inconspicuous regarding the product-based group. It is worth mentioning that the difference in fluency scores between the three CCL is completely acceptable, inasmuch as tasks with different CCL required the learners to produce texts in different time spans and with different word limits.

A two-way ANCOVA was conducted to compare the effect of using the three approaches to teaching writing on the participants' post-test fluency achievements, while simultaneously controlling for the pre-test differences as the covariate in the analysis. The main ANCOVA results are summarized in Table 5 below.

Table 5

Results of ANCOVA on the Fluency Scores in the Three Study Groups

\begin{tabular}{lllllll}
\hline Source & $\begin{array}{l}\text { Type III Sum } \\
\text { of Squares }\end{array}$ & $d f$ & $\begin{array}{l}\text { Mean } \\
\text { Square }\end{array}$ & $F$ & Sig. & $\begin{array}{l}\text { Partial Eta } \\
\text { Squared }\end{array}$ \\
\hline Corrected Model & 6455579.536 & 9 & 717286.615 & 4833.597 & .000 & .996 \\
Intercept & 2629.768 & 1 & 2629.768 & 17.721 & .000 & .094 \\
Pretest Fluency Scores & 357117.025 & 1 & 357117.025 & 2406.513 & .000 & .934 \\
CCL & 2146.276 & 2 & 1073.138 & 7.232 & .001 & .078 \\
Groups & 6671.738 & 2 & 3335.869 & 22.480 & .000 & .209 \\
CCL * Groups & 770.480 & 4 & 192.620 & 1.298 & .273 & .030 \\
Error & 25227.325 & 170 & 148.396 & & & \\
Total & 33226797.000 & 180 & & & & \\
Corrected Total & 6480806.861 & 179 & & & & \\
\hline
\end{tabular}

The ANCOVA results in Table 5 demonstrated a significant main effect for the Group variable, $F(2,170)=22.480, p<0.001$. Additionally, the Partial Eta Squared value $\left(\eta^{2}\right.$ $=.209$ ) implied that approximately $21 \%$ of the variance in the post-test fluency scores would be attributed to the approach adopted to teaching writing. Moreover, there was a statistically non-significant interaction between the tasks' CCL and different approaches to teaching writing, $F(4,170)=1.298, p=.273$, indicating that the difference between the three groups in terms of fluency was not dependent on the tasks' level of cognitive complexity.

Table 6 shows the results of Bonferroni corrected post-hoc comparisons to determine the location of the difference between the three groups in terms of fluency.

Table 6

Pairwise Comparison between the Three Groups based on Estimated Marginal Means

\begin{tabular}{lllllll}
\hline \multirow{2}{*}{ (I) groups } & \multirow{2}{*}{$(\mathrm{J})$ groups } & Mean Difference & Std. & \multirow{2}{*}{ Sig. } & \multicolumn{2}{c}{ 95\% Confidence Interval for Difference } \\
& & $(\mathrm{I}-\mathrm{J})$ & Error & & Lower Bound & Upper Bound \\
\hline Mentor- & Product-based & 7.221 & 2.234 & .004 & 1.819 & 12.622 \\
based & Process-based & -7.853 & 2.227 & .002 & -13.238 & -2.467 \\
\hline Product- & Mentor-based & -7.221 & 2.234 & .004 & -12.622 & -1.819 \\
based & Process-based & -15.073 & 2.249 & .000 & -20.510 & -9.636 \\
\hline Process- & Mentor-based & 7.853 & 2.227 & .002 & 2.467 & 13.238 \\
based & Product-based & 15.073 & 2.249 & .000 & 9.636 & 20.510 \\
\hline
\end{tabular}


As shown in Table 6, there were significant differences between the mentor-based and process-based groups $(p<.05)$, the mentor-based and product-based groups $(p<.05)$, and the product-based and process-based groups $(p<.001)$.

\section{DISCUSSION}

This section includes a comprehensive discussion interpreting the study's key findings in relation to the results reported in the previous literature.

\section{Discussing the Findings Related to the First Research Question}

Based on the results of quantitative analysis of the data, mentor text modelling was found to be as effective as product-based approach in enhancing the learners' accuracy in writing tasks with different CCL. In addition, both mentor text modelling and product-based approach were found to be more effective than process-based approach in improving the learners' accuracy in writing tasks with different CCL. In other words, among the three different approaches investigated in the current study (i.e., productbased, process-based, and mentor text modelling), mentor text modelling and product based approach were proved to be superior to a process-based approach in terms of improving accuracy in writing, regardless of the writing tasks' level of cognitive complexity. In general, the findings certified the view often expressed by scholars that the employment of a product-based approach yields an accurate written craft putting particular emphasis on accuracy of final product in terms of grammatical structure (e.g., Balakrishnan, 2010; Jouzdani et.al., 2015; Sakoda, 2008; Sarhady, 2015; Sun, 2009).

The capability of mentor text modelling and product-based approaches to improve accuracy could be attributed to the similar principles underlying the two approaches. As defined earlier, both the approaches promote the idea of utilizing well-structured models to enhance learners' writing proficiency; however, the model texts took an active role in the former but a passive role in the latter. According to Gholami Pasand and Bazarmaj Haghi's (2013), the employment of model texts in a process-product approach to teaching writing would enhance writing accuracy. The finding also substantiated Saeidi and Sahebkheir's (2011) claim that using model essays affect EFL learners' writing performance in terms of accuracy. Another similarity between the two approaches is being much more teacher-centered compared to a process-based approach which is basically student-centered (Sakoda, 2008).

The efficacy of mentor text modelling approach in improving the learners' accuracy, as revealed in the current study, backed up the results obtained by Kane (2012) who investigated the impact of a mentor text inquiry approach to narrative writing instruction on attitude, self-efficacy, and writing performance of fourth grade students in an urban elementary school. Employing a multiple case study design, she concluded that most of the students improved in the areas of language structure, conventions, and organization, as well as improving in terms of self-efficacy as a result of benefiting from mentor text modelling.

In another phase, the quantitative analysis of the data indicated that the superiority of both mentor text modelling and product-based approach over process-based approach in 
improving the learners' level of accuracy was not dependent on the writing tasks' level of cognitive complexity, inasmuch as the results were remarkably similar regarding the writing tasks with all three levels of cognitive complexity (i.e., high, moderate, and low). Although, there is not an existing empirical study on the relationship between writing tasks' CCL and the effectiveness of different approaches to teaching writing, the distinct feature of the two approaches, which is providing learners with model texts that are commensurate with the target texts' cognitive complexity level, can well vindicate the non-significant effect of tasks' cognitive complexity on the effectiveness of the two approaches in improving EFL learners' accuracy in writing.

\section{Discussing the Findings Related to the Second Research Question}

Shifting the discussion's focus onto fluency, the results suggested a number of revealing outcomes. The quantitative analysis of the data revealed that mentor text modeling affected the learners' fluency in writing tasks with all three levels of cognitive complexity significantly more than a product-based instruction. The approach (mentor text modelling), however, was detected to be less effective than a process-based approach to teaching writing.

The efficacy of the process-based writing instruction in enhancing the learners' writing fluency, as revealed in the current study, corroborated the view has been repeatedly verified by scholars that having learners to concentrate on the processes involved in writing rather than a sheer focus on the ultimate written product can result in a better writing performance (Barnett, 1992; Chenoweth \& Hayes, 2003; Polio, 2001). This finding is also consistent with the results drawn from Shahrokhi Mehr's (2017) study which revealed that the participants who received process-based instruction outperformed their counterparts in the product group in terms of fluency.

Having benefited from the instructor's guidance, the learners who received a processbased instruction worked on various writing tasks, as well as gradually receiving their peer corrective feedback. Composing several drafts while working in groups, pairs, and individually may have fostered the learners' positive attitude toward writing skill. According to Berninger and Fan (2007), positive attitude toward writing push learners to invest more in it, whereas negative attitude inhibits effective writing to a great extent. On the other hand, having been seriously involved in different stages associated with writing process, learners could be capable to break down the daunting skill of writing into its component parts. This may have alleviated the frustration and complexity of writing in a foreign language to some extent freeing learners from the cognitive constraints on writing process.

Another potential reason for the efficacy of process-based approach in improving writing fluency would be the fact that receiving instruction based on such an approach can lower the psychological barriers of writing in a foreign language. Anxiety, as ascertained by Sawkins (1971) and Thompson (1981) would be regarded as the most notable example. The primary reason for writing anxiety would be the learners' concerns about being evaluated and, as a result, confronting the errors (Graves, 1994; Routman, 1996). Benefiting from a process-based writing instruction, learners' anxiety 
may be reduced to a great extent, inasmuch as errors are supposed to be minimized during the process of text production. Accordingly, learners can cultivate a positive attitude toward writing and, as a result, achieve success in conveying their thoughts on a given topic with consummate ease.

Although, based on the study results, adopting a process-based approach was proved to be significantly more effective than mentor text modelling in improving fluency in writing, it is not reasonable to infer that mentor text modelling approach is not a beneficial approach to teaching writing. Taking the priority of mentor text modelling over a product-based approach in improving writing fluency as well as the practical constraints of adopting a process-based approach in real setting into account, mentor text modelling approach still deserves to be regarded as an alternative to the conventional approaches.

\section{CONCLUSION}

In an EFL context like Iran, where English exposure is very limited, reaching an agreement on the most effective approach to teaching writing is of paramount importance. To identify the most effective instructional practices to move students towards the highest levels of writing achievement, the current research study investigated the effect of three approaches; namely, process-based approach, productbased approach, and mentor-text modeling on EFL learners' accuracy and fluency in writing tasks with different levels of cognitive complexity. A deep examination of the three approaches revealed that adopting a process-based approach yielded higher degrees of fluency playing down the seriousness of psychological barriers impeding successful conveyance of the meaning such as anxiety and obsession with being grammatically right. In contrast, product-based approach detected to be much more effective in forming more accurate texts through over teaching of the target texts' quality such as punctuation, sentence structures, text structures, paragraphing, etc. Nonetheless, mentor text modelling, as a balanced approach incorporating product and process approaches' insights, was detected to be effective in improving both accuracy and fluency in writing and, as a result, deserved to be regarded as an alternative to the two conventional approaches to teaching writing. The study also came to a conclusion that the efficacy of the three approaches under investigation was seemed to be independent of writing task's level of cognitive complexity.

The study provided adequate evidence for the view that involving EFL learners in deconstructing well-structured and authority-approved model texts is a useful form of pedagogical practice which fosters accuracy and fluency in writing. Having been exposed to ideal responses to different writing tasks, EFL learners would be able to make more and more contributions to the class analysing the texts in groups, pairs, and individually. Pedagogically, the efficacy of mentor text modelling approach in improving both accuracy and fluency, would urge EFL teachers to adopt such an approach as an alternative to the conventional approaches. Moreover, syllabus designers in their efforts to enrich writing syllabuses are recommended to include different types of mentor texts relevant to every writing task. 
Owing to the study limitations and delimitations including the limited number of participants, the fairly short length of the training sessions, and the employment of particular measures (instead of using multiple measures) to gage accuracy and fluency in writing, the findings are recommended to be generalized cautiously. Additionally, a careful replication of the study in different EFL contexts may echo the results more confidently. Future researchers may also explore a clear answer to the question of whether or not the psychological barriers impeding the writing process such as anxiety and concerns for being evaluated in terms of grammatical structures can be rectified as the result of adopting mentor text modelling approach to teaching writing.

\section{REFERENCES}

Ahmadian, M. J. \& Tavakoli, M. (2011). The effects of simultaneous use of careful online planning and task repetition on accuracy, fluency, and complexity of EFL learners' oral production. Language Teaching Research, 15: 35-59.

Akkaya, N. \& Kirmiz, F. S. (2010). Relationship between attitudes to reading and time allotted to writing in primary education, Procedia Social and Behavioral Sciences, 47424746.

Balakrishnan, M. S. (2010). Writing case: The difference from a case study research methodology and a teaching case study. Oxford: Oxford University Press.

Barnett, M. A. (1992). Writing as a process. North-East Conference. Retrieved from https://www.web.pdx.edu

Bayat, N. (2014). The effect of the process writing approach on writing success and anxiety. Educational Science: Theory \& Practice, 14/3, 1133-1141.

Berninger, V. \& Fan, W. (2007). The structural relationship between writing attitude and writing achievement in first and third grade students. Contemporary Educational Psychology, 32/3, 516-536.

Bloom, B. S. (2001). Taxonomy of educational objectives and writing intended learning outcomes statements. International Assembly for Collegiate Business Education (IACBE), USA.

Chenoweth, A. \& Hayes, J. (2003). The inner voice. Written Communication, 20/1, 99118.

Christensen, F. (1967). Notes toward a new rhetoric: Six essays for teachers. New York, NY: Harper \& Row.

Ellis, R. (2003). Task-based language learning and teaching. Oxford: Oxford University Press.

Gholami Pasand, P. \& Bazarmaj Haghi, E. (2013). Process-product approach to writing: the effect of model essays on EFL learners' writing accuracy. International Journal of Applied Linguistics \& English Literature, 2/1, 75-79. 
Gilabert, R.; Baron, J. \& Llanes, A. (2009). Manipulating cognitive complexity across task types and its impact on learners' interaction during oral performance. IRAL, 47: 367-395

Graham, S.; Harris, K. R. \& Mason, L. (2005). Improving the writing performance, knowledge, and self-efficacy of struggling young writers: The effects of self-regulated strategy development. Contemporary Educational Psychology, 30/2, 207-241.

Graves, D. H. (1994). A fresh look at writing. Portsmouth: Heinemann.

Hasan, K. \& Akhand, M. (2010). Approaches to writing in EFL/ESL context: Balancing product and process in writing class at tertiary level. Journal of NELTA, 15/1, 77-88.

Hashemnezhad, H. \& Hashemnezhad, N. (2012). A comparative study of product, process, and post-process approaches in Iranian EFL students' writing skill. Journal of Language Teaching and Research, 3/4, 722-729.

Hyland, K. (2003). Second Language Writing. Cambridge University Press

Jahin, J. H. \& Idrees, M. W. (2012). EFL major student teachers' writing proficiency and attitudes towards learning English. Journal of Educational \& Psychologic Sciences, 4, 10-72. Journal of Multidisciplinary Studies. 1/4, 55-58.

Jouzdani, M.; Biria, R. \& Mohammadi, M. (2015). The effect of product-based and process-based teaching on writing efficiency of Iranian EFL learners. International Journal of Research Studies in Language Learning, 1/1, 1-6.

Kane, C. M. K. (2012). Investigating the Impact of a Mentor Text Inquiry Approach to Narrative Writing Instruction on Attitude, Self-efficacy, and Writing Processes of Fourth Grade Students in an Urban Elementary School. Doctoral Dissertation, San Diego State University, San Diego, Argentina.

Klimova, B. F. (2014). Approaches to the Teaching of Writing Skills. Procedia Social and Behavioral Sciences, 11/2, 147-151.

Kroll, B. (1990). Considerations for Teaching an ESL/EFL Writing Course. In M. Celce-Murcia (Ed.), Teaching English as a second or foreign language (3rd ed., pp. 219-232). New York: Heinle \& Heinle.

Likaj, M. (2015). Teaching writing through Communicative Approach in Military English. Journal of Education and Practice, 6/2, 102-107.

Luchini, P. L. (2010). Evaluating the effectiveness of a complimentary approach to teaching writing skills. International Journal of Language Studies (IJLS), 4/3, 73-92.

Matsuda P. K. (2003). Second language writing in the twentieth century: A situated historical perspective. In B.

Kroll (Ed.) Exploring the dynamics of second language writing. Cambridge: Cambridge University Press. 
Mosayebnazhad, F. \& Assadi Aidinlou, N. (2015). The Effect of systemic genre instruction on the writing performance of Iranian EFL high school students. MAGNT Research Report, 3/1, 377-388.

Nunan, D. (1999). Second Language Teaching and Learning. Florence: Heinle \& Heinle Publishers.

Polio, C. (2001). Research methodology in second language writing research: The case of text based studies. In T. Silva and P. K. Matsuda (Eds.), On Second Language Writing (pp. 91-115). Mahwah, NJ: Lawrence Erlbaum.

Raimes, A. (1983). Techniques in Teaching Writing (pp. 1-30). Oxford: Oxford University Press.

Reppen, R. (1995). A genre-based approach to content writing instruction. TESOL Journal, 4/2, 32-35.

Robinson, P. (2001). Task complexity, task difficulty, and task production: exploring interactions in a componential framework. Applied Linguistics, 22/1, 27-57.

Robinson, P. (2005). Cognitive complexity and task sequencing: studies in a componential framework for second language task design. International Review of Applied Linguistics, 43: 1-32.

Robinson, P. (2007). Task complexity, theory of mind, and intentional reasoning: effects on L2 speech production, interaction, uptake and perceptions of task difficulty. International Review of Applied Linguistics, 45/3, 193-213.

Rollinson, P. (2005). Using peer feedback in the ESL writing class. ELT Journal, 59/1, 23-30.

Routman, R. (1996). Literacy at the crossroads: Crucial talk about reading, writing, and other teaching dilemmas. Portsmouth, NH: Heinemann.

Rusinovci, X. (2015). Teaching writing through process-genre based approach. USChina Education Review A, 5/10, 699-705.

Saeidi, M. \& Sahebkheir, F., (2011). The effect of model essays on accuracy and complexity of EFL learners' writing performance. Middle-East Journal of Scientific Research, 10/1, 130-137.

Sakoda, N. (2008). The distinction between process based and product based approaches to teaching writing and its effects on classroom methodology. (1141-1156). Retrieved from:

Sarhady, T. (2015). The effect of product/process-oriented approach to teaching and learning writing skill on university student performances. International Journal of Language and Applied Linguistics, 1/2, 7-12. 
Sawkins, M. W. (1971). The oral responses of selected fifth grade children to questions concerning their writing expression. Buffalo, NY: Buffalo State: University of New York.

Shahrokhi Mehr, S. (2017). The impact of product and process approach on Iranian EFL learners' writing ability and their attitudes toward writing skill, International Journal of English Linguistics, 7/2, 158-166.

Silva, T. (1990). Second language com- position instruction: Developments, issues, and directions in ESL. In B. Kroll (Ed.), Second Language Writing: Research Insights for the Classroom (pp. 11-36). New York: Cambridge University Press.

Skehan, P. (1996). Second language acquisition research and task-based instruction. In J. Willis \& D. Willis (Eds.), Challenge and Change in Language Teaching. London: Heinemann.

Spigelman, C. \& Grobman, L. (2005). On location: Theory and practice in classroombased writing tutoring. Logan: Utah State University Press.

Sun, C. H. \& Feng, G. (2009). Process approach to teaching writing applied in different teaching models. English Language Teaching Journal, 2/1, 150-155.

Sutikno, M. K. (2008). Responding to students' writing. (Teaching writing or assessing it?). Journal Pendidikan Penabur, 10/7, 51-59.

Tabachnick, B. G. \& Fidell, L. S., (2007). Using multivariate statistics. Boston: Pearson/Allyn \& Bacon.

Tangpermpoon, T. (2008). Integrated approaches to improve students writing skills for English major students. ABAC Journal, 28/2, 1-9.

Thompson, M. O. (1981). A workshop: Coping with writing anxiety. Paper presented at the Post-Conference Workshop of the National Council of Teachers of English, Minneapolis, MN.

Torghabeh, R.A.; Hashemi, M.R. \& Ahmadi, H. Sh. (2010). Writing through literature: a novel approach to EFL writing instruction. Iranian EFL Journal, 6/4, 7-23.

Trejo, J. (2014). Imagining Possibilities. In L. Bridges, Editor. Open a World of Possible: Real Stories About the Joy and Power of Reading. New York: Scholastic.

Webb, N. L. (1997). Criterion for alignment of expectations and assessments in mathematics and science education. Washington DC: Council of Chief State School Affairs.

Wenden, A. (1987). Incorporating learner training in the classroom. In A. Wenden \& J. Rubin (Eds.), Learner strategies in language learning (pp. 159-68). Englewood Cliffs, NJ: Prentice Hall.

Winston, W. (1987). Teaching writing: Analyzing the craft of professional writers. Quarterly of the National Writing Project, 9/4, 20-25. 
Wolfe-Quintero, K.; Inagaki, S. \& Kim, H. Y. (1998). Second language development in writing: Measures of fluency, accuracy and complexity. Technical report 17. Manoa, Hawai'i US: University of Hawai'i Press.

Yuan, F. \& Ellis, R. (2003). The effects of pre-task planning and on-line planning on fluency, complexity and accuracy in L2 monologic oral production. Applied Linguistics, 24: 1-27.

Zamel, V. (1982). Writing: The process of discovering meaning. TESOL Quarterly, 16/2, 195-209. 